PODGURSKA V.

Zhytomyr State Ivan Franko University Applicant of the Department of Pedagogy Ukraine

\title{
PATRIOTIC EDUCATION OF TRAINERS OF EDUCATION AS A PSYCHOLOGICAL-PEDAGOGICAL PROBLEM
}

The article is devoted to the study of the essential characteristics of patriotism. The views of different scholars on the substantiation of the notion of patriotism are analyzed, the importance of forming the spirituality of the student youth and the education of patriotism is substantiated. According to the results of the analysis of reference books and periodicals, different approaches to the definition of the term "patriotism" have been identified. Particular attention must be paid to the formation of a patriotic feelings in the emotional and sensual sphere, because human emotions and feelings most clearly express the spiritual needs and aspirations of man, his attitude to reality. Stages of education of patriotism of the person, which are formed from preschool age to adolescence, structure of patriotism are determined. It is determined that it is necessary to distinguish between varieties of patriotism: ethnic, territorial, state. he content of patriotic education, most researchers see in the formation of such civic and patriotic qualities, such as: civil-patriotic self-awareness, worldview and belief; high civil responsibility while performing professional duties; social activity in everyday life and activities; knowledge of the history and culture of your country; love for the Fatherland and readiness to protect it.

The tasks of patriotic education are successfully solved in the event that the educational process is carried out systematically and comprehensively, if this activity includes both subjects and objects of patriotic education; coordination of educational actions of all categories of educators is ensured, individual qualities and peculiarities of pupils are taken into account, conditions under which the process of patriotic education is taking place, various forms and methods are used. youth.

Key words: patriotism, national patriotic upbringing, territorial, state patriotism, patriotic consciousness, student Стаття надійшла до редакції 27.02. 2018 р.

УДК 378.016:[331.548:004]

НАТАЛІЯ ПОНОМАРЬОВА

Харківський національний педагогічний університет імені Г.С. Сковороди

\section{ЗМІСТ НАВЧАЛЬНО-МЕТОДИЧНОГО ЗАБЕЗПЕЧЕННЯ ПІДГОТОВКИ МАЙБУТНІХ УЧИТЕЛІВ ІНФОРМАТИКИ ДО ПРОФОРІЄНТАЦІЙНОЇ РОБОТИ ЗІ ШКОЛЯРАМИ}

Визначено мету та зміст підготовки майбутніх учителів інформатики до профорієнтації школярів на IT-спеціальності . Для впровадження розробленої моделі такої підготовки розроблено ії̈ навчальнометодичне забезпечення. У відповідності до визначених етапів підготовки майбутнього вчителя інформатики до професійної орієнтації школярів на ІT-спеціальності встановлено зміст ії навчальнометодичного забезпечення: на базовому етапі підготовки - для навчальних дисциплін «Педагогіка» та «Психологія»; на продуктивному етапі підготовки - для навчальних дисциплін «Методика навчання інформатики», «Теорія та методика профорієнтаційної роботи вчителя інформатики» та пропедевтичної практики; на рефлексивно-корекційному етапі - для навчальних дисциплін «Методика навчання інформатики», «Практика з інформаційних технологій», педагогічна практика. Згідно з викладеним підготовлено навчальні програми модулів названих навчальних дисциплін, які потребують оновлення, програми авторських дисциплін, програми практик, навчальні посібники тощо.

Ключові слова: ІТ-спеціальності, профорієнтаційна роботи, учитель інформатики, підготовка учителів інформатики, навчально-методичне забезпечення.

Постановка проблеми. Профорієнтаційна робота - один з головних напрямів навчально-виховної роботи в загальноосвітній школі, спрямований на активізацію професійного самовизначення учнів, їх підготовку до свідомого вибору професії та визначення свого місця у суспільстві (Проект...). У складних умовах сьогодення особливого значення набуває профорієнтаційна діяльність учителя інформатики, пов'язана із спрямуванням професійного самовизначення учнів в ІT-сфері. На думку експертів, недостатня ефективність підготовки фахівців для ІT-галузі в Україні перешкоджає використанню потенційно наявного фактору доступності 
кваліфікованих кадрових IT-ресурсів як великої конкурентної переваги і чинника економічного зростання країни (Щедролосьєв, 2010). У профорієнтаційній роботі зі школярами на ІТ-спеціальності вчитель інформатики виконує інформаційно-орієнтуючу, діагностуючу, консультуючу, організаційну, координуючу, спрямовуючу функцію та функцію орієнтації у медіа-просторі, для чого учитель інформатики має одержати належну підготовку (Пономарьова, 2018).

Аналіз останніх досліджень і публікацій. В психолого-педагогічних дослідженнях науковців розгорнуто представлено різні аспекти підготовки педагогічних кадрів. Проблеми підготовки майбутніх вчителів інформатики до професійної діяльності, розвитку інформаційної культури та формування професійних компетентностей досліджували Н. Апатова, Л.Білоусова, І.Булах, А. Верлань, Ю. Горошко, А.Гуржій, 0. Гончарова, О. Данильчук, В Дем'яненко, Ю. Жук, І. Іваськів, В. Ізвозчиков, $\quad$ В. Осадчий, В. Руденко, О.Співаковський, Є.Смірнова-Трибульська, Ю. Триус, Г. Цибко, М. Шкіль та інші. Методологічні засади здійснення підготовки майбутніх вчителів інформатики розробляються у працях В.Бикова, М.Жалдака, О.Спіріна, В.Радула, В.Шовкуна, С. Овчарова, Н. Морзе та інших. На змісті та особливостях методичної підготовки вчителя інформатики зосереджені дослідження Н. Балик, Л. Брескіной, Ю. Рамського, С. Семерікова, В. Лапінського, М. Лапчика та інших. Значний внесок до розробки психолого-педагогічних засад підготовки майбутніх учителів до професійної орієнтації школярів зробили І. Ареф'єв, В. Витязєв, В. Зінченко, С. Золотухіна, Г. Клімов, Є.Павлютенков, В.Рижов, В.Симоненко, М.Степаненков, Б. Ханжарова, В.Харламенко, М. Ховрич, Н. Шадієв, О. Негрівода, Д. Завітренко, М. Чумак, І. Чорна, Г. Шліхта, Л.Тименко та інші. Разом 3 тим, попри наявність таких різнобічних напрацювань виявляється недостатність досліджень, спрямованих на обґрунтування теоретичних і методичних засад професійної підготовки майбутніх учителів інформатики у вищих педагогічних навчальних закладах до професійної орієнтації школярів на IT-спеціальності.

Вивчення освітньо-професійних програм (навчальних планів, програм навчальних дисциплін, програм педагогічних практик), підручників і посібників, а також іншого навчально-методичного забезпечення навчально-виховного процесу у вищих педагогічних навчальних закладах України засвідчило відсутність належного висвітлення питань підготовки майбутніх вчителів інформатики до здійснення професійної орієнтації школярів на ІT-спеціальності і дало підставу для висновку про необхідність внесення суттєвих змін у процес підготовки майбутніх учителів до такої діяльності (Пономарьова, 2017).

Підготовка майбутніх учителів інформатики у вищих педагогічних навальних закладах до професійної орієнтації учнів має за мету формування в студентів готовності до здійснення профорієнтаційної роботи зі школярами на IT-спеціальності. У структурі готовності виділено мотиваційний, когнітивний, практичнодіяльнісний та рефлексивні компоненти. Нами розроблена структурно-функціональна модель підготовки майбутнього вчителя інформатики до професійної орієнтації школярів на IT-спеціальності (Пономарьова, 2018), яка відтворює багатоетапний процес підготовки майбутніх учителів інформатики до професійної орієнтації школярів на ІT-спеціальності, що має бути реалізованим в ході опанування навчальних дисциплін психолого-педагогічного, методичного, інформативного спрямування. Впровадження створеної моделі 3 необхідністю потребує розробки відповідного навчально-методичного забезпечення.

Мета статті: розкрити зміст навчально-методичного забезпечення підготовки майбутніх учителів інформатики до професійної орієнтації школярів на ІT-спеціальності.

Виклад основного матеріалу. Формування готовності майбутнього вчителя інформатики до професійної орієнтації школярів на ІT-спеціальності здійснюється систематично й поетапно - в процесі чітко структурованої навчальної діяльності. Виділяємо базовий, продуктивний та рефлексивно-корекційній етапи такої підготовки (Пономарьова, 2018).

Базовий етап має забезпечити набуття майбутніми педагогами загальних психолого-педагогічних знань i вмінь щодо здійснення профорієнтаційної роботи зі школярами. На цьому етапі опорними навчальними дисциплінами, такими, що безпосередньо забезпечують підготовку студентів до професійної орієнтації школярів на IT-спеціальності як складової їх майбутньої професійної педагогічної діяльності, виступають «Психологія» та «Педагогіка».

Для підготовки майбутніх учителів інформатики до професійної орієнтації школярів на ІT-спеціальності важливо, щоб у змісті курсу психології були висвітлені питання сутності та специфіки процесу професійного самовизначення школярів у різні вікові періоди, психологічні особливості успішного профорієнтаційного інформування, консультування та діагностики школярів. Засвоєння таких знань є необхідним для майбутнього вчителя, оскільки саме вони в подальшому постають основою для визначення доцільного змісту профорієнтаційної роботи зі школярами, відбору найбільш ефективних ії форм та методів. За результатом вивчення курсу психології майбутні вчителі інформатики мають одержати вміння здійснювати вивчення особистості школяра в контексті його професійного самовизначення. Таким чином, реалізація розробленої моделі потребує розширення змісту курсу психології модулем «Психологічні засади професійної орієнтації школярів». До складу модулю входять теми «Професійне самовизначення як психологічна категорія», «Психологічні особливості здійснення професійної орієнтації», «Психологічна діагностика школярів у професійній орієнтації». 
Для формування готовності до проведення профорієнтаційної роботи зі школярами на IT-спеціальності у рамках вивчення курсу «Педагогіка» майбутні вчителі інформатики мають засвоїти ключові принципи професійної орієнтації школярів; мету та загальний зміст профорієнтаційної роботи; основні види профорієнтаційної діяльності та ефективні форми і методи їх реалізації у навчально-виховному процесі. Окрім того, у майбутніх учителів інформатики мають бути сформовані уміння конкретизувати мету та завдання профорієнтаційної роботи, адекватно добирати її зміст, форми і методи. 3 метою вирішення окреслених завдань зміст навчальної дисципліни «Педагогіка» має бути доповненим. Так, до модулю «Дидактика», розділу «Актуальні питання дидактики» вводиться тема «Педагогічні основи професійної орієнтації школярів».

Продуктивний етап підготовки майбутніх учителів інформатики до професійної орієнтації школярів на ITспеціальності передбачає оволодіння студентами знаннями, необхідними для здійснення роботи 3 професійної орієнтації школярів безпосередньо на IT-спеціальності, опанування відповідними уміннями, формування у студентів потреби та мотивів здійснення такої профорієнтаційної роботи. Опорними навчальними дисциплінами щодо підготовки студентів до професійної орієнтації школярів на ITспеціальності на цьому етапі виступають «Методика навчання інформатики», пропедевтична практика та розроблений авторський навчальний курс «Теорія та методика профорієнтаційної роботи вчителя інформатики».

Для формування готовності майбутніх учителів інформатики до профорієнтаційної роботи зі школярами необхідно забезпечити їх знаннями про функції вчителя інформатики у професійній орієнтації школярів на ITспецальності, про зміст і особливості профорієнтаційної роботи вчителя інформатики на IT-спеціальності, сформувати переконання майбутніх учителів інформатики у цінності здійснення профорієнтаційної роботи зі школярами на ІТ-спеціальності та усвідомлення ними власної відповідальності за її успішність. Це зумовлює необхідність розширення та оновлення у вказаному напрямі змісту модулів навчальної дисципліни «Методика навчання інформатики», які вивчаються на третьому році навчання студентів: «Предмет інформатики в системі загальноосвітніх знань», «Принципи, методи та організаційні форми навчання інформатики»

3 метою формування готовності майбутніх учителів інформатики до професійної орієнтації школярів на IT-спеціальності під час пропедевтичної практики слід поповнити завдання практики в межах змістових модулів «Ознайомлення з організацією навчально-виховного роботи у загальноосвітньому навчальному закладі», «Ознайомлення з організацією навчально-методичної роботи вчителя-предметника».

Саме на цьому етапі підготовки майбутніх вчителів інформатики до професійної орієнтації школярів на ITспеціальності вводимо дисципліну «Теорія та методика профорієнтаційної роботи вчителя інформатики». Як свідчить аналіз навчальних планів з підготовки вчителів інформатики, вивчення цієї навчальної дисципліни органічно вписується до переліку вибіркових навчальних дисциплін третього року навчання (6-го семестру). Навчальна дисципліна «Теорія та методика профорієнтаційної роботи вчителя інформатики» зорієнтована на опанування студентами спеціальних знань та умінь щодо здійснення професійної орієнтації школярів на ITспеціальності. Основними завданнями вивчення цієї дисципліни є засвоєння знань про специфіку складових професійної орієнтації школярів на ІT-спеціальності; набуття вмінь проведення профорієнтаційної роботи зі школярами на IT-спеціальності на усіх етапах їі здійснення; формування переконань та мотивів проведення профорієнтаційної роботи зі школярами на ІT-спеціальності.

Рефлексивно-корекційний етап спрямований на розширення i корекцію у майбутніх учителів інформатики набутих знань і умінь щодо професійної орієнтації школярів на ІТ-спеціальності, оволодіння студентами здатністю оцінювати результати власної профорієнтаційної роботи, формування в них потреби до власного професійного удосконалення у вказаному напрямі, на формуванню готовності до активного власного професійного вдосконалення у напрямі професійної орієнтації школярів на ІТ-спеціальності. Даний етап охоплює четвертий рік навчання майбутніх учителів інформатики у вищих педагогічних начальних закладах. На рефлексивно-корекційному етапі опорними дисциплінами з підготовки студентів до професійної орієнтації школярів на IT-спеціальності $€$ «Методика навчання інформатики», «Практика 3 інформаційних технологій», педагогічна практика.

Щодо навчальної дисципліни «Методика навчання інформатики», то на четвертому році навчання для реалізації розробленої моделі підготовки майбутніх учителів до професійної орієнтації школярів на ITспеціальності до модулів «Методика вивчення основ моделювання, алгоритмізації та програмування», «Методика вивчення прикладного програмного забезпечення загального призначення», «Методика вивчення комп'ютерних мереж та систем мультимедіа» необхідно включити розгляд питань про можливості впливу на формування інтересу учнів до напрямів професійної діяльності IT-фахівців, пов'язаних із вказаними технологіями, через зміст навчального матеріалу відповідних тем шкільного курсу інформатики. Модуль «Міжпредметні зв'язки шкільного курсу інформатики» розширюється питаннями про методику ознайомлення школярів із різноплановими застосуваннями інформаційно-комунікаційних технологій у різних видах людської професійної діяльності.

У професійній підготовці майбутніх учителів інформатики до профорієнтаційної роботи чинне місце належить практиці з інформаційних технологій, мета якої - формування у студентів-майбутніх учителів 
інформатики умінь та навичок застосування інформаційно-комунікаційних технологій у профорієнтаційній роботі на IT-спеціальності з учнями основної та старшої школи. Згідно з навчальними планами, термін проходження практики 3 інформаційних технологій - четвертий рік навчання, 7 семестр. Основними завданнями практики з інформаційних технологій визначаємо забезпечення засвоєння студентами основних напрямів застосування інформаційно-комунікаційних технологій у профорієнтаційній роботі на ITспеціальності; формування умінь та навичок використання засобів інформаційно-комунікаційних технологій для організації профорієнтаційної роботі на ІТ-спеціальності з учнями основної та старшої школи; вивчення особливостей використання інтерактивних форм профорієнтаційної роботи на ІТ-спеціальності з учнями основної та старшої школи (Пономарьова, 2016).

Проведення профорієнтаційної роботи зі школярами на ІТ-спеціальності як однієї із складових професійної діяльності вчителя інформатики наразі діючими програмами педагогічної практики не передбачено, тому уявляється необхідним уточнити програму практики, доповнив такими завданнями, які дозволять студентам оволодіти вміннями та навичками: впровадження сучасних ефективних форм, методів та засобів профорієнтаційної роботи зі школярами на IT-спеціальності; виділення у навчальному матеріалі шкільного курсу інформатики новітні засоби профорієнтаційної роботи та органічно включати їх до навчального процесу; критичного аналізу відповідності змісту своєї профорієнтаційної роботи зі школярами на IT-спеціальності суспільним умовам та вимогам поточного стану ринку праці. Для забезпечення досягнення вказаної мети змістовий модуль педагогічної практики «Навчально-методична робота» поповнено темою «Організація профорієнтаційної роботи вчителя інформатики».

Зауважимо, що на всіх етапах підготовки набуті майбутніми вчителями інформатики знання, уміння та навички мають бути затребуваними і при виконанні студентами індивідуальних навчально-дослідницьких завдань, курсових, наукових робіт тощо.

Згідно з викладеним нами підготовлено навчальні програми модулів названих навчальних дисциплін, які потребують оновлення, програми авторських дисциплін, програми практик, навчальні посібники тощо.

Висновки і перспективи подальших розвідок. У відповідності до визначених етапів підготовки майбутнього вчителя інформатики до професійної орієнтації школярів на IT-спеціальності встановлено зміст іiї навчально-методичного забезпечення. А саме, на базовому етапі підготовки - для навчальних дисциплін «Педагогіка» та «Психологія»; на продуктивному етапі підготовки - для навчальних дисциплін «Методика навчання інформатики», «Теорія та методика профорієнтаційної роботи вчителя інформатики» та пропедевтичної практики; на рефлексивно-корекційному етапі - для навчальних дисциплін «Методика навчання інформатики», «Практика з інформаційних технологій», педагогічна практика.

Розроблене навчально-методичного забезпечення дозволяє на практиці впровадити створену модель підготовки майбутніх учителів інформатики до професійної орієнтації школярів на IT-спеціальності у закладах вищої педагогічної освіти. Перспективним напрямом подальших наукових розвідок уявляється проведення експериментальних досліджень щодо оцінки ефективності проведеної роботи.

\section{Список використаних джерел}

Проект Національної стратегії розвитку освіти в Україні на 2012- 2021 роки [Електронний ресурс].- Режим доступу: http://www.kharkivosvita.net.ua/ files/Rozv_osviti.pdf.

Щедролосьєв Д. Є. Особливості підготовки ІТ- фахівців в українських вищих навчальних закладах / Д. Є. Щедролосьєв // Комп'ютер у школі та сім'ї. - 2010. - № 8. - С. 12- 15. - Режим доступу: http://nbuv.gov.ua/UJRN/komp_2010_8_4

Пономарьова Н.О. Підготовка майбутніх учителів інформатики до профорієнтаційної роботи у загальноосвітніх навчальних закладах: монографія / Н.О. Пономарьова. - Х. ХНПУ імені Г.С.Сковороди, 2018. - 325 с.

Пономарьова Н.О. Аналіз стану підготовки майбутніх вчителів інформатики у вищих педагогічних навчальних закладах України до роботи з професійної орієнтації школярів на IT- спеціальності / Н.О.Пономарьова // ScienceRise: Pedagogical Education. - 2017. - № 7 (15). - C. 45-48, DOI: 10.15587/2519-4984.2017.107978

Пономарьова Н.О. Профорієнтаційний аспект у практиці підготовки майбутнього вчителя інформатики / Н.О.Пономарьова // Комп'ютер у школі та сім'ї. - 2016. - № 8. - С. 49- 52

\section{References}

Proekt Natsionalnoi stratehii rozvytku osvity v Ukraini na 2012- 2021 roky [Elektronnyi resurs].- Rezhym dostupu: http://www.kharkivosvita.net.ua/ files/Rozv_osviti.pdf.

Shchedrolosiev D. Ye. Osoblyvosti pidhotovky IT- fakhivtsiv v ukrainskykh vyshchykh navchalnykh zakladakh / D. Ye. Shchedrolosiev // Kompiuter u shkoli ta simi. - 2010. - № 8. - S. 12- 15. - Rezhym dostupu: http://nbuv.gov.ua/UJRN/komp_2010_8_4

Ponomarova N.O. Pidhotovka maibutnikh uchyteliv informatyky do proforiientatsiinoi roboty u zahalnoosvitnikh navchalnykh zakladakh: monohrafiia / N.O. Ponomarova. - Kh. KhNPU imeni H.S.Skovorody, 2018. - 325 s.

Ponomarova N.O. Analiz stanu pidhotovky maibutnikh vchyteliv informatyky u vyshchykh pedahohichnykh navchalnykh zakladakh Ukrainy do roboty $\mathrm{z}$ profesiinoi oriientatsii shkoliariv na IT- spetsialnosti / N.O.Ponomarova // ScienceRise: Pedagogical Education. - 2017. - № 7 (15). - S. 45-48, DOI: 10.15587/2519-4984.2017.107978 
Ponomarova N.O. Proforiientatsiinyi aspekt u praktytsi pidhotovky maibutnoho vchytelia informatyky / N.O.Ponomarova // Kompiuter u shkoli ta simi. - 2016. - № 8. - S. 49- 52

\section{PONOMAROVA N.}

H.S. Skovoroda Kharkiv National Pedagogical University, Ukraine

\section{CONTENTS OF EDUCATIONAL AND METHODOLOGICAL SUPPORT FOR PREPARATION OF FUTURE TEACHERS OF INFORMATICS TO CAREER GUIDANCE OF PUPILS}

The purpose of training future teachers of informatics for the career guidance of pupils on IT-specialties is formation of their readiness for such work. For implementation of the developed structural-functional model of the preparation in higher pedagogical institutions of the future teacher of informatics to career guidance of pupils on IT-specialties is developed educational and methodical support. In accordance with the selected stages of the preparation of the future teacher of informatics to career guidance of pupils on the IT-specialty, the content of its teaching and methodological support is established. at the basic stage of preparation - for educational disciplines "Pedagogy" and "Psychology", at the productive stage of preparation - for educational disciplines "Methods of teaching informatics", "Theory and methodology of career guidance work of the teacher of informatics" and propaedeutic practice, at a reflexive-corrective stage - for educational disciplines "Methods of teaching informatics", "Practice in information technology", teaching practice. According to the above, is developed the curricula of the modules of the academic disciplines that require updating are prepared, a program of author's disciplines, programs of pedagogical and other types of practice, textbooks etc.

Key words: IT-specialties, career guidance work, teacher of informatics, preparation of teacher of informatics, educational and methodological support

Стаття надійшла до редакції 27.02.2018 р.

УДК 37.02

IHHA PACCOXA

ЛЮДМИЛА БЛАЖКО

ТЕТЯНА ГАЛАЙДА

Полтавський національний технічний університет імені Юрія Кондратюка

\section{ЕКОНОМІЧНІ ПРИКЛАДНІ ЗАДАЧІ ЯК ЗАСІБ ПІДВИЩЕННЯ МОТИВАЦІЇ ПРИ ВИВЧЕННІ ВИЩОЇ МАТЕМАТИКИ В ТЕХНІЧНИХ ЗВО}

Розглянуто проблеми мотивації студентів при вивченні вищої математики студентами економічних спеціальностей. Показано шляхи її підвищення за рахунок використання прикладних задач, пов'язаних з проблемами даного регіону.

Ключові слова: мотивація, мотиви, прикладні задачі, практичні задачі, математичне моделювання, математичні моделі, лінійна алгебра

Актуальність теми. Аналіз психологічної, педагогічної літератури та багаторічний досвід роботи у ЗВО свідчить, що для сучасного студента важливо не лише отримати та засвоїти теоретичну інформацію, а й навчитися використовувати їі для практичних потреб в межах майбутньої професійної діяльності. Результати здобуття теоретичних знань та практичних навичок тісно пов'язані з мотивами, якими при цьому керується студент.

Аналіз досліджень і публікацій. Результати досліджень серед першокурсників свідчать, що тільки 43\% опитаних мають орієнтацію на оволодіння професією, решта 57\% не мають наміру працювати за фахом (Ільїн, 2000). О.В. Гилюн, провівши аналогічні дослідження на основі аналізу матеріалів соціологічних опитувань студентів ДНУ за період з 2000 до 2010 року, робить висновок: «... конкретна цілеспрямованість освітніх мотивацій студентів в останні роки знижується» (Гилюн, 2012). Таким чином, можна зробити висновок, що тільки половина студентів мають мотив - оволодіння професією, мотиви решти інші і швидше пов'язані 3 одержанням диплома, а не професійних навичок. Тому одним із основних завдань сучасних педагогів стає формування у студентів стійкої мотивації до навчання. На думку В. Є. Михайличенко та В. В. Полянської, дослідження проблеми формування мотивації навчально-пізнавальної діяльності у вищому навчальному 